\title{
Risk factors for Blastocystis infection in HIV/ AIDS patients with highly active antiretroviral therapy in Southwest China
}

\author{
Shun-Xian Zhang ${ }^{1,2 \dagger}$, Fen-Yan Kang ${ }^{3 \dagger}$, Jia-Xu Chen ${ }^{4,5}$, Li-Guang Tian ${ }^{4,5^{*}+}$ (D) and Lan-Lan Geng ${ }^{2^{* \dagger}}$
}

\begin{abstract}
Background: Blastocystis is a widespread zoonotic protozoan of mammalian species, especially in HIV/AIDS individuals. The aim of this study was to analyze the prevalence and risk factors related with Blastocystis infection among HIV/AIDS patients in Southwest China.

Methods: The cross-sectional study was performed in 311 HIV/AIDS cases in Tengchong City, Yunnan Province from July 2016 to March 2017. For each subject, stool specimen was collected to detect the Blastocystis, and the blood sample was used to detect HIV virus load and CD4 ${ }^{+} \mathrm{T}$ cell count, in addition, structured questionnaire was used to collect the basic information and risk factors.

Findings: The result showed that the detection rate of Blastocystis was 3.86\% (95\% Cl: 2.22-6.62) among HIV/AIDS patients. Both raising animal $(O R=12.93,95 \% \mathrm{Cl}: 1.54-108.36)$ and drinking un-boiled water $(O R=8.17,95 \% \mathrm{Cl}: 1.76-$ 37.90) were risk factors for Blastocystis infection in HIV/AIDS individuals. In addition, the interaction of CD4 ${ }^{+} T$ cell count and HIV virus load was also contribution to Blastocystis infection $(P=0.007)$.

Conclusions: A high prevalence of Blastocystis infection was found in HIV/AIDS patients in Tengchong. Poor hygienic habits, the interaction of HIV virus load and $C D 4^{+} T$ cell count were identified as main risk factors for infection. These results will help us to develop efficient control strategies to intervene with and prevent the occurrence of Blastocystis among HIV-infected individuals.
\end{abstract}

Keywords: Blastocystis, HIV/AIDS, Co-infection, Risk factor, Interaction

\section{Multilingual abstracts}

Please see Additional file 1 for translations of the abstract into the five official working languages of the United Nations.

\section{Background}

Despite the expansion of antiretroviral treatment programme several years ago, 940000 people died from AIDS related illnesses and 1.8 million people became newly infected with HIV/AIDS, it remains a global

\footnotetext{
*Correspondence: jztlg@126.com; 13622237569@163.com

†Shun-Xian Zhang, Fen-Yan Kang, Li-Guang Tian and Lan-Lan Geng contributed equally to this work.

${ }^{4}$ National Institute of Parasitic Diseases, Chinese Center for Disease Control and Prevention, Shanghai 200025, People's Republic of China

${ }^{2}$ Department of Gastroenterology, Guangzhou Women and Children's

Medical Center, Guangzhou Medical University, Guangzhou 510623, People's

Republic of China

Full list of author information is available at the end of the article
}

public health problem [1-4]. Currently, dramatic expansion of the pandemic has brought about a significant change in the prevalent of pathogens all over the world, especially in developing countries [5-7]. HIV/AIDS and many intestinal pathogen, including Cryptosporidium parvum, Blastocystis [8-10], previously were considered to be sporadic or zoonotic infection, becoming opportunistic infection for individual.

Blastocystis is a single-cell, anaerobic eukaryotic organism [11, 12]. It is one of the most frequently intestinal parasite that found in human beings and other animals in the worldwide [13]. And about 1 billion people in the worldwide were infected by Blastocystis with ubiquitous asymptomatic infection [11, 12]. The detection rate of Blastocystis was $0.5-57.0 \%$ in developed countries $[14,15]$, and $30.0-60.0 \%$ in developing countries, especially in tropical, subtropical and poorly sanitized 
countries or regions [12]. Most importantly, the presence of the Blastocystis has been well documented among HIV/AIDS patients $[5,6,16]$. Some studies have reported that the prevalence was $0.8-2.2 \%$ in HIVinfected individuals [6, 17], whereas the detection of Blastocystis was $16.2 \%$ in HIV-infected patients conducted in China [5]. Taken together, these findings suggested that the prevalence of the Blastocystis among HIV/AIDS patients was variation in different regions of the world, is essential to further our knowledge of the epidemiology and clinical relevance of this organism in HIV-positive patients.

However, no available reports about the risk factors of Blastocystis infection among HIV-infected patients in Southwest China. This cross-sectional study was conducted to explore the risk factors affecting Blastocystis infection among HIV/AIDS, providing strategies for Blastocystis prevention and treatment.

\section{Methods}

\section{Study design and subjects}

From 1st July 2016 to 31st March 2017, this crosssectional study was conducted in the Tengchong City, Yunan Province, China. A total number of 2279 HIVinfected patients were registered in Tengchong Center for Disease Control and Prevention, these patients were received standardized treatment, such as the highly active antiretroviral therapy (HAART), in the People's Hospital of Tengchong City and the Tengchong Center for Disease Control and Prevention.

The participants in this study were randomly selected. The inclusion criteria for selection of participants involved who over 5 years old and is able to give written informed consent or to obtain assent by legal guardians, and is absence of obvious severe defects of development or malignant diseases affecting investigation procedures, while inadequate fecal sample, incomplete questionnaire, and refusal to participate were ruled out.

\section{Sample size calculation}

The sample size was determined using the formula for sample size calculation [7].

$$
\mathrm{n}=\frac{z_{\alpha}^{2} p(1-p)}{\delta^{2}}, \alpha=0.05, \mathrm{Z}_{0.05}=1.96, \delta=\text { precision of the }
$$

event of interest $=0.05$, where $n=$ sample size, $p=$ prevalence of Blastocystis among HIV/AIDS patients $=16.23 \%$ [5]. A minimum size was 209 cases, considering the $10 \%$ loss follow up, the final minimum size was $209(1+$ $0.1)=230$ participants. Finally, 311 HIV/AIDS patients were enrolled into this study.

\section{Questionnaire survey}

One standardized structural questionnaire was designed to obtain socioeconomic and demographic description about each HIV/AIDS patient, including the age, gender, height, weight, education, residence, marital status, occupation and presence of symptoms, total family members and minor members in family, HIV infection time, route and medical treatments. In addition, environmental conditions, such as water supply, drinking water, toilet type and presence of domestic animals, were also included. This work were performed by trained doctors or nurses.

\section{Stool collection}

Each fecal specimen was collected with sterile container and delivered to the laboratory of the People's Hospital of Tengchong City, and stored at $-70^{\circ} \mathrm{C}$.

\section{Blood collection}

Two milliliter venous blood of the aseptic processing procedures from each subject were collected with heparinized biomedical polymer anticoagulative tube, and transported to the laboratory of the People's Hospital of Tengchong City immediately.

\section{Laboratory testing \\ Stool DNA extraction}

Total genomic DNA was extracted with the QIAmp DNA Stool Mini Kit (Qiagen, Hilden, Germany) from stool specimen according to the manufacturer's recommended procedures. Finally, genomic DNA was obtained and stored at $-70^{\circ} \mathrm{C}$ until use.

\section{Molecular detection of Blastocystis}

Polymerase chain reaction (PCR) amplification was conducted to detect Blastocystis using the primers, targeted at the 18 ribosomal small subunitribosomal ribonucleic acid (SSU rRNA) coding region gene [18]. The forward primer was 5'-GGAGGTAGTGACAA TAAATC-3', and the reverse primer was $5^{\prime}$ ACTAGGAATTCCTCGTTCATG-3', and the length of the PCR amplification product was $1100 \mathrm{bp}$ [18], all primers were synthesized by Sangon Biotech Company (Shanghai, China). The PCR reaction mixture ( $25 \mu \mathrm{l}$ total volume) consisted of $12.5 \mu \mathrm{l} 2 \times \mathrm{TaKaRa}$ $\mathrm{Taq}^{\mathrm{mi}}$ mixture (TaKaRa Bio Inc., Shiga, Japan), $2 \mu \mathrm{l}$ genomic DNA template, $1 \mu \mathrm{l}$ each of $10 \mu \mathrm{mol} / \mathrm{L}$ forward primer and reverse primer, and $8.5 \mu \mathrm{l}$ water. The PCR conditions consisted of one denaturing cycle at $94{ }^{\circ} \mathrm{C}$ for $5 \mathrm{~min}, 40$ cycles involving denaturation at $94{ }^{\circ} \mathrm{C}$ for $30 \mathrm{~s}$, annealing at $53^{\circ} \mathrm{C}$ for $1 \mathrm{~min}$, and extending at $72{ }^{\circ} \mathrm{C}$ for $1 \mathrm{~min}$, followed by $72^{\circ} \mathrm{C}$ for 10 min. The PCR product was subjected to $1 \%$ agarose gels at $120 \mathrm{~V}$ for $40 \mathrm{~min}$ and observed under UV light. The PCR product of suspected positive case was sent to purify and sequence using the dideoxy-terminal method by the Applied Biosystems 3130 Genetic Analyzer (Applied Biosystems, Foster City, California, 
USA). The result was compared with known sequences listed in the GenBank database maintained by the US National Library of Medicine (http://www. ncbi.nlm.nih.gov/BLAST/), using the basic local alignment search tool (Blast).

\section{Analysis of $\mathrm{CD}^{+} \mathrm{T}$ cell counts}

Blood sample was centrifuged at $1000 \times g$ for $10 \mathrm{~min}$, and the supernatant (serum) was carefully collected, aliquoted in RNase-free EP tubes. The peripheral blood mononuclear cells were obtained from the precipitation of the whole blood and suspended in phosphate buffer solution (PBS) followed by adding antibodies of anti-human CD11a labeled FITC and PE conjugated anti-human CD4 (BD Biosciences, Franklin Lakes, New Jersey, USA). After incubation at $4{ }^{\circ} \mathrm{C}$ for $10 \mathrm{~min}$, cells were suspended and centrifuged at $1000 \times g$ for $10 \mathrm{~min}$ again to remove the supernatant. The cells were suspended in $0.5 \mathrm{ml}$ PBS and analyzed by BD FACS Count System (BD Biosciences, Franklin Lakes, New Jersey, USA). Negative control was set to determine the cut-off value.

\section{Detection of HIV virus load}

Then HIV virus load in the serum was determined with NucliSens HIV-1 QT Amplification Kit (BioMerieux, Marcyl'Etoile, France) using a virus load detector NucliSENS ECL (BioMerieux, Marcyl'Etoile, France) following the manufacturer's instruction. The copy number of viral nucleic acid were measured to represent viral genome titers.

\section{Data analysis}

The database was generated with EpiData 3.1 software (The EpiData Association, Odense, Denmark), and all data were recorded with double individuals and tested for consistency. Statistical analysis was performed with the IBM SPSS Statistics 25.0 software package (International Business Machines Corporation, Armonk, New York, United States). Odds ratio (OR) and 95\% confidence interval $(C I)$ of categorical variables were calculated using two tailed, Chi-square or Fisher's exact test. Quantitative variable was described as mean, median, standard deviation or inter-quartile range (IQR), quantitative variable was compared by rank-sum test, analysis of variance or $t$ test, significant difference was considered as the level of $P<0.05$ with two-tailed test. The variables with $P<0.20$ in the univariate analysis were introduced in the multivariate logistic regression analysis. The stepwise regression method was used. The proposed standard was $P>0.20$, the final test level was $P<0.05$ with two-tailed.

\section{Results}

Basic information and clinical symptoms of subjects

A total number of $311 \mathrm{HIV}$ patients, including 149 male and 162 female, were recruited in our study from 1st July 2016 to 31st March 2017. The average age, weight, and height were 40 years (95\% CI: 39-41), 57 kilogramme (95\% CI: 56-58) and $162 \mathrm{~cm}$ (95\% CI: $161-$ $162)$, respectively. While the average number of family individual and juvenile were 4 (95\% CI: 4-5) and 1 (95\% CI: 1-1), respectively.

Among 311 HIV/AIDS patients, in the grade of education, the person with junior middle school-level education was most, followed by primary school-level education, high school-level education and university or college-level education. Based on mode of transmission, sexual transmission was predominant transmission route, followed by syringe transmission and mother to child transmission. What's more, the average $\mathrm{CD} 4^{+} \mathrm{T}$ cell count and HIV virus load were 520 cells/ $\mu$ l (95\% CI: 495-544) and 2587 copies/ml (95\% CI: 315-4859), respectively. The average treatment time was 68 months (95\% CI: 64-72) for all patients.

In addition, the most common clinical symptoms were loss of appetence (19.3, 95\% CI: 15.3-24.0), followed by skin itching (17.0, 95\% CI: 13.3-21.6), abdominal distension (16.1, 95\% CI: 12.4-20.6), pruritus (13.5, 95\% CI: 10.1-17.8), abdominal pain (12.9, 95\% CI: 9.6-17.0), anemia (2.9, 95\% CI: $1.5-5.4)$ and chronic diarrhea (1.0, 95\% CI: 0.3-2.8).

\section{Blastocystis prevalence and the relationship between Blastocystis infection and clinical symptom}

Twelve cases of 311 HIV/AIDS subjects were infected with Blastocystis, and the detection rate was 3.86\% (95\% CI: 2.22-6.82) (Fig. 1, Additional file 2). No significant association was observed between Blastocystis infection and clinical symptoms, such as diarrhea $(P=0.999)$, abdominal distension $(P=0.999)$, loss of appetence $(P=$ $0.060)$, itchy skin $(P=0.437)$, perianal pruritus $(P=$ $0.063)$ and anemia $(P=0.320)$.

\section{Risk factors for the Blastocystis infection with univariate analysis}

Univariate analysis has revealed that drinking water, raising livestock, HIV infection route, $\mathrm{CD}^{+}{ }^{+} \mathrm{T}$ cell count and HIV virus load were closely association with Blastocystis infection (Table 1). In addition, the potential risks $(P<0.20)$ for the Blastocystis infection were gender and washing hand after defecation (Table 1). Whereas, several factors have no influence on Blastocystis infection among HIV-infected patients (Table 1), such as age, nationality, residence, education level, marriage, family member, body mass index (BMI), water source, toilet 


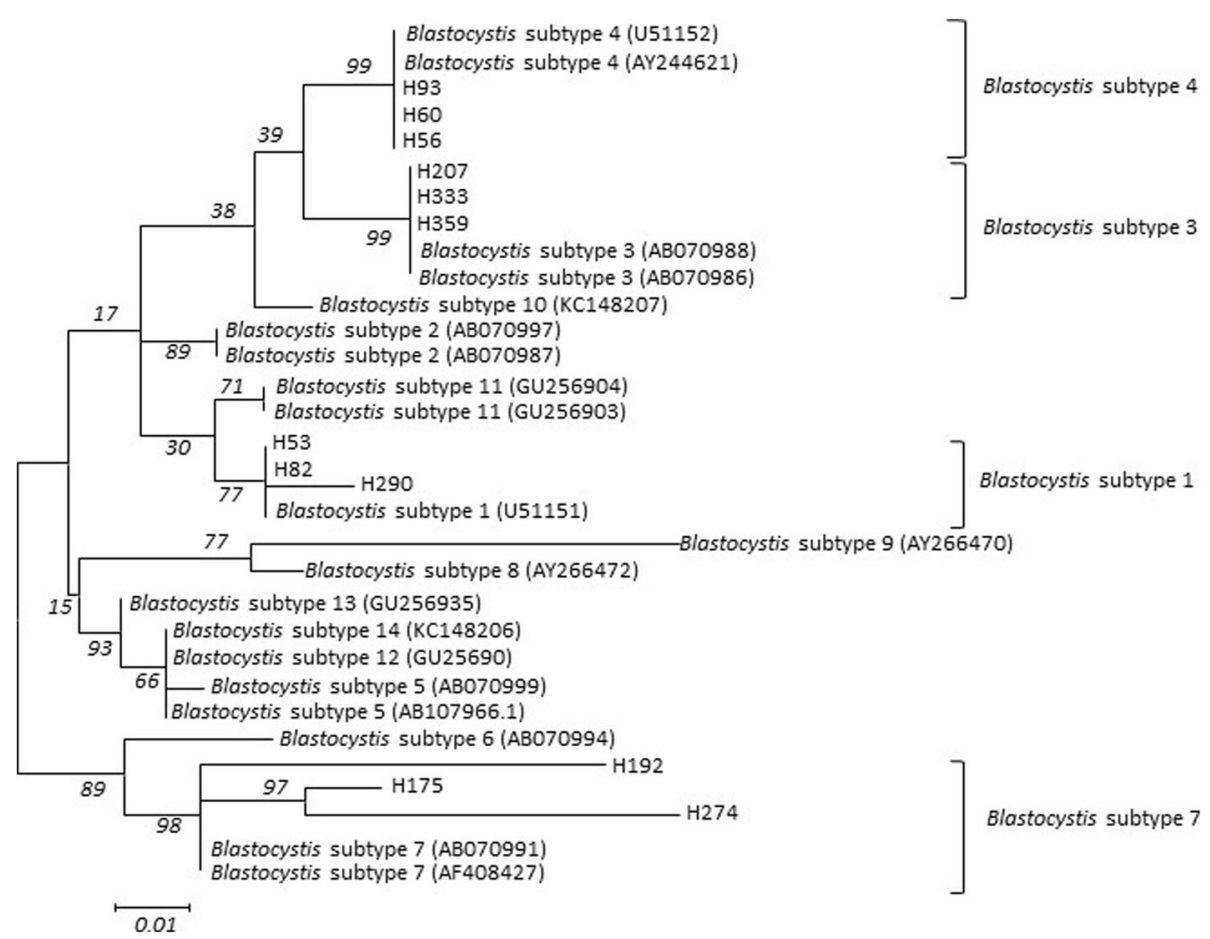

Fig. 1 Generation of evolutionary tree of Blastocystis with neighbor-joining analysis. The reference sequence was obtained from GeneBank. 12 cases were diagnosed as Blastocystis infection, Blastocystis subtype 1, subtype 3, subtype 4 and subtype 7 were three, identically

type, keeping pet, household member chronic diarrhea and HIV clinical stage.

\section{Risk factors for the Blastocystis infection with multivariate analysis}

Based on these variables (drinking water, raising livestock, HIV infection route, $\mathrm{CD} 4^{+} \mathrm{T}$ cell count, HIV virus load, gender and washing hand after defecation) were involved in the multivariate model, further analysis showed that only four factors were association with Blastocystis infection as follows: raising animal, drinking water, CD4 ${ }^{+} \mathrm{T}$ cell count and HIV virus load (Table 2).

\section{Interaction effect among $\mathrm{CD}^{+}{ }^{+} \mathrm{T}$ cell count and HIV virus load for Blastocystis infection}

Upon the threshold of $\mathrm{CD}^{+} \mathrm{T}$ cell count and HIV virus load was set into 500 cells $/ \mu \mathrm{l}$ and 50 copies $/ \mathrm{ml}$, respectively. The detection rate of Blastocystis was different in these four groups (Table 3). At the same time, the interaction variable between the HIV virus load and $\mathrm{CD}^{+} \mathrm{T}$ cell count, named $\mathrm{CD}^{+} \mathrm{T}^{*} \mathrm{HIV}$, which was introduced in Table 3. As for the new variable $\mathrm{CD}^{+} \mathrm{T}^{*} \mathrm{HIV}$ (Table 3 ), the group 4 was defined as reference group (dummy variable), and analysis was performed again, including the factor that drinking water, raising animal, HIV infection route, $\mathrm{CD} 4^{+} \mathrm{T}$ cell count, HIV virus load, gender and washing hand after defecation. The furher results showed that raising animal and drinking un-boiled water were the risk factors for Blastocystis infection among HIV/AIDS cases, and the new variable $\mathrm{CD} 4^{+}$ T*HIV was also contribution the Blastocystis prevalence (Table 2). In addition, the detection rate of Blastocystis in subjects with HIV virus load $<50$ copies/ml and $\mathrm{CD}^{+} \mathrm{T}<500$ cells/ $\mu \mathrm{l}$ was less than that in individuals with HIV virus load $\geq 50$ copies $/ \mathrm{ml}$ and $\mathrm{CD} 4^{+} \mathrm{T}<500$ cells $/ \mu \mathrm{l}(\mathrm{OR}=0.02,95 \% \mathrm{CI}: 0.00-$ 0.19 ), and the prevalence of Blastocystis in subjects with HIV virus load $\geq 50$ copies $/ \mathrm{ml}$ and $\mathrm{CD}_{4}^{+} \mathrm{T} \geq 500$ cells $/ \mu$ l was lower than that in individuals with HIV virus load $\geq 50$ copies $/ \mathrm{ml}$ and $\mathrm{CD}_{4}{ }^{+} \mathrm{T}<500$ cells $/ \mu \mathrm{l}$ $(O R=0.15,95 \%$ CI: 0.03-0.73) (Table 3).

\section{Discussion}

Blastocystis is one of the most common enteric protozoa in HIV-infected patient due to weaken immunity [19]. In this study, the detection rate of Blastocystis was $3.70 \%$ in HIV-infected patients, it was significant lower than that reported by others conducted in HIV/AIDS patients in China [5], and some developing countries, such as Ethiopia (10.6\%) [20] and Iran (19.0\%) [21]. Conversely, the detection rate of Blastocystis was higher than that in non-diarrhea subjects in China (32.6\%) [22]. However, the prevalence of Blastocystis in this study was closely to other studies conducted among non-diarrhea and nonHIV population $(4.0 \%)$ in urban area in China [23, 24], it 
Table 1 Single factor analysis of influencing factors for Blastocystis infection among HIV patients

\begin{tabular}{|c|c|c|c|c|c|c|}
\hline \multirow[t]{2}{*}{ Variable } & & \multirow{2}{*}{$\begin{array}{l}\text { Blastocystis } \\
(+) \\
n=12 \\
N(\%)\end{array}$} & \multirow{2}{*}{$\begin{array}{l}\text { Blastocystis } \\
(-) \\
n=299 \\
N(\%)\end{array}$} & \multirow{2}{*}{\multicolumn{3}{|c|}{ Univariate analysis }} \\
\hline & & & & & & \\
\hline \multirow{2}{*}{ Age } & $<40$ vear $(n=179)$ & $8(45)$ & $171(955)$ & $\overline{\chi^{2}}$ & 0515 & $O R(95 \% C l)$ \\
\hline & $\geq 40$ year $(n=132)$ & $4(3.0)$ & $128(97.0)$ & & & \\
\hline \multirow[t]{2}{*}{ Gender } & Male $(n=149)$ & $3(2.0)$ & $146(5.6)$ & 2.656 & 0.105 & $2.86(0.76-10.78)$ \\
\hline & Female $(n=162)$ & $9(98.0)$ & $153(94.6)$ & & & \\
\hline \multirow[t]{2}{*}{ Nationality } & Minority nationality $(n=11)$ & $1(9.1)$ & $11(90.9)$ & - & 0.356 & $0.38(0.04-3.24)$ \\
\hline & Han nationality $(n=300)$ & $10(3.7)$ & $289(96.3)$ & & & \\
\hline \multirow[t]{2}{*}{ Residence } & Urban $(n=260)$ & $10(3.8)$ & $250(96.2)$ & 0.001 & 0.980 & $1.02(0.22-4.80)$ \\
\hline & Rural area $(n=51)$ & $2(3.9)$ & $49(96.1)$ & & & \\
\hline \multirow[t]{4}{*}{ Education level } & Primary school $(n=132)$ & $6(4.5)$ & $126(95.5)$ & 1.583 & 0.633 & - \\
\hline & Junior middle school $(n=161)$ & $6(3.7)$ & $155(96.3)$ & & & \\
\hline & High school $(n=15)$ & $0(0.0)$ & $15(100.0)$ & & & \\
\hline & University or collage $(n=3)$ & $0(0.0)$ & $3(100.0)$ & & & \\
\hline \multirow[t]{4}{*}{ Marriage } & Unmarried $(n=25)$ & $0(0.0)$ & $25(100.0)$ & 4.487 & 0.213 & - \\
\hline & Married $(n=259)$ & $12(4.6)$ & $247(95.4)$ & & & \\
\hline & Married and living alone or widowed $(n=22)$ & $0(0.0)$ & $22(100.0)$ & & & \\
\hline & Other $(n=5)$ & $0(0.0)$ & $5(100.0)$ & & & \\
\hline \multirow[t]{2}{*}{ Family member } & $<5$ individuals $(n=48)$ & $1(2.1)$ & $47(97.9)$ & - & 0.701 & $2.05(0.26-16.27)$ \\
\hline & $\geq 5$ individuals $(n=263)$ & $11(42)$ & $252(95.8)$ & & & \\
\hline \multirow[t]{3}{*}{ Body mass index } & Underweight $(n=29)$ & $2(6.9)$ & $27(93.1)$ & 2.862 & 0.210 & - \\
\hline & Normal $(n=271)$ & $9(3.3)$ & $262(96.7)$ & & & \\
\hline & Overweight $(n=11)$ & $1(9.1)$ & $10(90.7)$ & & & \\
\hline \multirow[t]{2}{*}{ Drinking water } & Boiled water $(n=291)$ & $7(2.4)$ & $284(97.6)$ & - & $<0.001$ & $13.50(3.80-47.70)$ \\
\hline & Un-boiled water $(n=20)$ & $5(25.0)$ & $15(75.0)$ & & & \\
\hline \multirow[t]{2}{*}{ Water source } & No-tap water $(n=11)$ & $0(0.0)$ & $11(100.0)$ & - & 0.999 & - \\
\hline & Tap water $(n=300)$ & $12(4.0)$ & $288(96.0)$ & & & \\
\hline \multirow[t]{2}{*}{ Toilet type } & Water wash toilet $(n=135)$ & $3(2.2)$ & $132(97.8)$ & 1.722 & 0.789 & $2.37(0.63-8.93)$ \\
\hline & Un-water wash toilet $(n=176)$ & $9(5.1)$ & $167(94.9)$ & & & \\
\hline \multirow[t]{2}{*}{ Washing hand after defecation } & No $(n=12)$ & $2(16.7)$ & $10(3.3)$ & - & 0.071 & $0.17(0.03-0.90)$ \\
\hline & Yes $(n=299)$ & $10(3.3)$ & $289(96.7)$ & & & \\
\hline \multirow[t]{2}{*}{ Keeping pet } & No $(n=230)$ & $8(3.5)$ & $222(96.5)$ & - & 0.518 & $1.44(0.44-4.92)$ \\
\hline & Yes $(n=81)$ & $4(4.9)$ & $77(95.1)$ & & & \\
\hline \multirow[t]{2}{*}{ Raising animal } & No $(n=146)$ & $1(0.7)$ & $145(99.3)$ & - & 0.006 & $10.36(1.32-81.23)$ \\
\hline & Yes $(n=165)$ & $11(6.7)$ & $154(93.3)$ & & & \\
\hline \multirow[t]{3}{*}{ HIV infection route } & Syringe $(n=18)$ & $3(16.7)$ & 15 (83.3) & 6.239 & 0.044 & - \\
\hline & Mother to children $(n=6)$ & $0(0.0)$ & $6(100.00)$ & & & \\
\hline & $\operatorname{Sex}(n=287)$ & $9(3.1)$ & $278(96.9)$ & & & \\
\hline \multirow[t]{2}{*}{ Take antiviral drug } & No $(n=2)$ & $0(0.0)$ & $2(100.0)$ & - & 0.999 & $1.04(1.02-10.06)$ \\
\hline & Yes $(n=309)$ & $12(3.9)$ & $297(96.1)$ & & & \\
\hline \multirow[t]{2}{*}{ Household member chronic diarrhea } & No $(n=294)$ & $10(3.4)$ & $2(11.8)$ & - & 0.134 & $3.79(0.76-18.84)$ \\
\hline & Yes $(n=17)$ & $2(11.8)$ & $15(88.2)$ & & & \\
\hline $\mathrm{CD}^{+} \mathrm{T}$ cell count & $<500(n=139)$ & $1(0.6)$ & $171(99.4)$ & 11.141 & 0.001 & $0.07(0.01-0.53)$ \\
\hline & $\geq 500(n=172)$ & $10(3.6)$ & $268(96.4)$ & & & \\
\hline
\end{tabular}


Table 1 Single factor analysis of influencing factors for Blastocystis infection among HIV patients (Continued)

\begin{tabular}{|c|c|c|c|c|c|c|}
\hline \multirow[t]{2}{*}{ Variable } & & \multirow{2}{*}{$\begin{array}{l}\text { Blastocystis } \\
(+) \\
n=12 \\
N(\%)\end{array}$} & \multirow{2}{*}{$\begin{array}{l}\text { Blastocystis } \\
(-) \\
n=299 \\
N(\%)\end{array}$} & \multicolumn{3}{|c|}{ Univariate analysis } \\
\hline & & & & $\overline{\chi^{2}}$ & $P$ value & OR $(95 \% C l)$ \\
\hline \multirow[t]{2}{*}{ HIV virus load } & $<50(n=282)$ & $7(2.5)$ & $275(97.5)$ & - & 0.002 & $8.18(2.41-27.75)$ \\
\hline & $\geq 50(n=29)$ & $5(17.2)$ & $24(82.8)$ & & & \\
\hline \multirow[t]{4}{*}{ HIV clinical stage } & I stage $(n=138)$ & $7(5.1)$ & $131(94.9)$ & 2.439 & 0.486 & - \\
\hline & Il stage $(n=73)$ & $3(4.1)$ & 70 (95.9) & & & \\
\hline & III stage $(n=82)$ & $2(2.4)$ & $80(97.6)$ & & & \\
\hline & IV stage $(n=18)$ & $0(0.0)$ & $18(100.0)$ & & & \\
\hline
\end{tabular}

The "-" symbol indicates the data was not be calculated

OR Odd ratio, $\mathrm{Cl}$ Confidence interval

may be attributed to the subject enrolled in this study, once HIV/AIDS patient was found in China, the large dose antiviral drug was used to treat, resulting in the low HIV virus load in serum, at the same time, the high immune status of patients can prevent intestinal protozoa infection to some extent, in addition, some broadspectrum antibiotics were used to prevent opportunistic infection in the processes of the standardized treatment for HIV/AIDS patient.

In line with other study [22], the result also showed that drinking un-boiled water was risk factor for Blastocystis infection among HIV/AIDS patients, it may increase the infection chance for intestinal protozoa, especially in HIV/AIDS patients. What's more, raising animal was another risk factor, it was consist with the report by Wang et al. showed that the HIV/AIDS patients could be infected by frequently contacting with livestock infected with Blastocystis [25]. Hence, the economic condition, raising livestock, and lifestyle remain to be improved, it is important event in blocking the infection of the Blastocystis and reducing the Blastocystis prevalence.

In this study, the average number of $\mathrm{CD}^{+}{ }^{+} \mathrm{T}$ cell count was 453 cells/ $\mu \mathrm{l}$ in HIV cases infected with Blastocystis, it was lower than that of in healthy people (>500 cells/ $\mu \mathrm{l})$. A study by Fekadu et al. showed that $\mathrm{CD}^{+} \mathrm{T}$ cell count will be degradation among HIV/AIDS patient [26]. Implying weaken immunity caused by low $\mathrm{CD} 4^{+} \mathrm{T}$ cell count may contribute Blastocystis infection in HIV/AIDS patients, and it was reasonable that the HIV/AIDS cases should be receive standardized treatment and longterm monitoring [21]. However, other study have showed that low $\mathrm{CD}^{+} \mathrm{T}$ cell count was not major risk factor for Blastocystis infection [27], for instance, no significant differences of Blastocystis infection was observed in HIV/AIDS individuals with or without $\mathrm{CD}^{+} \mathrm{T}$ cell count more than 200 cells/ $\mu$ l [7], and

Table 2 Multivariate logistic regression analysis of influencing factors for Blastocystis infection among HIV patients

\begin{tabular}{|c|c|c|c|c|c|c|}
\hline Variable & $B$ & SE & Wald & $d f$ & $P$ value & OR $(95 \% C l)$ \\
\hline Raising livestock & 2.548 & 1.082 & 5.54 & 1 & 0.019 & $12.78(1.53-106.63)$ \\
\hline Drinking water & 2.109 & 0.781 & 7.286 & 1 & 0.007 & $8.24(1.78-38.12)$ \\
\hline $\mathrm{CD}^{+} \mathrm{T}$ count & 2.377 & 1.088 & 4.773 & 1 & 0.029 & $10.75(1.28-90.90)$ \\
\hline HIV virus load & 1.769 & 0.764 & 5.365 & 1 & 0.021 & $5.86(1.31-26.19)$ \\
\hline Constant & -9.208 & 2.886 & 10.184 & 1 & $<0.001$ & - \\
\hline \multicolumn{7}{|c|}{ Dummy variable was defined and entered in multivariate logistic regression model } \\
\hline Raising animal & 2.559 & 1.085 & 5.568 & 1 & 0.018 & $12.93(1.54-108.36)$ \\
\hline Drinking water & 2.100 & 0.783 & 7.195 & 1 & 0.007 & $8.17(1.76-37.90)$ \\
\hline $\mathrm{CD}^{+} \mathrm{T}^{*} \mathrm{HIV}$ & & & 12.199 & 3 & 0.007 & - \\
\hline $\mathrm{CD}^{+} \mathrm{T}^{*} \mathrm{HIV}(1)$ & -4.034 & 1.203 & 11.248 & 1 & 0.001 & $0.02(0.00-0.19)$ \\
\hline$C D 4^{+} T^{*} H I V(2)$ & -19.829 & 14457.616 & $<0.001$ & 1 & 0.999 & - \\
\hline$C D 4^{+} T^{*} H I V(3)$ & -1.869 & 0.793 & 5.554 & 1 & 0.018 & $0.15(0.03-0.73)$ \\
\hline Constant & -7.990 & 2.267 & 12.422 & 1 & $<0.001$ & - \\
\hline
\end{tabular}

The "-" symbol indicates the data was not be calculated

$B$ Beta, SE Standard error, OR Odd ratio, Cl Confidence interval 
Table 3 Effect of HIV virus load and CD4 ${ }^{+} T$ cell count on Blastocystis infection among HIV patients

\begin{tabular}{|c|c|c|c|c|c|}
\hline Group & $\begin{array}{l}\text { Blastocystis (+) } \\
N\end{array}$ & $\begin{array}{l}\text { Blastocystis (-) } \\
N\end{array}$ & $\begin{array}{l}\text { Total } \\
N\end{array}$ & $\begin{array}{l}\text { Detection rate } \\
(\%, 95 \mathrm{Cl})\end{array}$ & Group \\
\hline HIV virus load < 50 copies/ml & 7 & 275 & 282 & $2.48(1.21-5.03)$ & - \\
\hline HIV virus load $\geq 50$ copies/ml & 5 & 24 & 29 & $17.20(7.60-34.55)$ & - \\
\hline $\mathrm{CD}^{+} \mathrm{T}<500 \mathrm{cells} / \mu \mathrm{l}$ & 11 & 128 & 139 & $7.91(4.47-13.61)$ & - \\
\hline $\mathrm{CD}^{+} \mathrm{T} \geq 500 \mathrm{cells} / \mu \mathrm{l}$ & 1 & 171 & 172 & $0.58(0.10-3.22)$ & - \\
\hline HIV virus load $<50$ copies $/ \mathrm{ml}$ and $C D 4^{+} T<500$ cells $/ \mu \mathrm{l}$ & 6 & 111 & 117 & $5.13(2.37-10.12)$ & 1 \\
\hline HIV virus load $<50$ copies $/ \mathrm{ml}$ and $C D 4^{+} T \geq 500$ cells $/ \mu \mathrm{l}$ & 1 & 164 & 165 & $0.61(0.11-3.36)$ & 2 \\
\hline HIV virus load $\geq 50$ copies $/ \mathrm{ml}$ and $\mathrm{CD}^{+} \mathrm{T} \geq 500$ cells $/ \mu \mathrm{l}$ & 0 & 7 & 7 & $0.00(0.00-35.43)$ & 3 \\
\hline HIV virus load $\geq 50$ copies $/ \mathrm{ml}$ and $C D 4^{+} T<500$ cells $/ \mu l$ & 5 & 17 & 22 & $22.73(10.74-43.44)$ & 4 (Reference) \\
\hline
\end{tabular}

The "_" symbol indicates the data was not be calculated

another study showed that compared to HIV/AIDS patients with $\mathrm{CD}_{4}^{+} \mathrm{T}$ cell count less than 50 cells/ $\mu \mathrm{l}$, patients with $\mathrm{CD}_{4}^{+} \mathrm{T}$ cell count more than 50 cells/ $\mu \mathrm{l}$ were not more likely to be infected by Blastocystis [28]. In addition, another study have also suggested that high HIV virus load was risk factor for intestinal protozoa infection [29], while another study found that the HIV concentration has no effect on the enteric parasites infection [6]. Interestingly, our study revealed that the prevalence of Blastocystis in HIV/ AIDS cases with high HIV virus load and low $\mathrm{CD} 4^{+}$ $\mathrm{T}$ cell count was much higher than that in other groups, implying that Blastocystis infection among HIV/AIDS subjects was not only association with HIV virus load and $\mathrm{CD}^{+} \mathrm{T}$ cell count, but also depended on the interaction effect between these two variables. These findings suggested that $\mathrm{CD} 4^{+} \mathrm{T}$ cell count have inversely correlated with HIV virus load, both of them are the risk factors of Blastocystis infection among HIV/AIDS subjects.

There were several shortcomings in this study needed to be addressed. It was a cross-sectional study and cannot be obtained causal conclusion. At the same time, data sparsity issue led to be fail to estimate for risk factors of Blastocystis infection among HIV/AIDS cases. Hence, the sample size should be expanded to explore the interaction effect between HIV virus load and $\mathrm{CD} 4^{+}$ $\mathrm{T}$ cell count during Blastocystis infection in future.

\section{Conclusions}

Both raising animal and drinking un-boiled water were risk factors for Blastocystis infection, and the interaction of $\mathrm{CD}_{4}^{+} \mathrm{T}$ cell count and HIV virus load was also contribution to Blastocystis infection. Thus, improvement of health education, good hygiene and living habit are important to prevent and control Blastocystis infection. In addition, HIV-infected individuals must be treated by with HAART, it could be effect to reduce the HIV virus load and prevent Blastocystis infection.

\section{Supplementary information}

Supplementary information accompanies this paper at https://doi.org/10. 1186/s40249-019-0596-7.

Additional file 1. Multilingual abstracts in the five official working languages of the United Nations.

Additional file 2. The sequence of Blastocystis in this study.

\section{Abbreviations}

AIDS: Acquired immune deficiency syndrome; Blast: Basic local alignment search tool; BMI: Body mass index; Cl: Confidence interval;

DNA: Deoxyribonucleic acid; HAART: Highly active antiretroviral therapy; HIV: Human immunodeficiency virus; IQR: Inter-quartile range; OR: Odd ratios; PBS: Phosphate buffer solution; PCR: Polymerase chain reaction;

RNA: Ribonucleic acid; SSU rRNA: Ribosomal small subunit, ribosomal ribonucleic acid

\section{Acknowledgements}

We sincerely thank the doctors and nurses in collecting stool specimens, investigating and reporting on the subjects, in addition, we special thanks to Yong-Kang Zhou who is from the First Affiliated Hospital of Lanzhou

University to make the evolutionary tree of Blastocystis.

\section{Authors' contributions}

SX-Z and FY-K performed the statistical analysis and drafted the manuscript, LL-G and JX-C conceived and designed the study, LG-T conducted the dates collected and Blastocystis detected. All authors read and approved the final version of the paper.

\section{Authors' information}

LG-T and LL-G are the corresponding authors of this paper of this article, SX$Z$ and $Y F-K$ contributed equally to this work.

\section{Funding}

The data analysis of this study was supported by China Postdoctoral Science Foundation Grant (No. 2018 M64303043) and the postdoctoral research funding from Guangzhou Women and Children's Medical Center (No. 50013001075), the field epidemiological investigation and Blastocystis detection were supported by the National Natural Science Foundation of China (No. 81473022), in addition, and the English edit was supported by the 13th FiveYear National Science and Technology Major Project for Infectious Diseases (No. 2017ZX1030550-002)

Availability of data and materials

Data of the study can be available upon request from the author (LG-T).

\section{Ethics approval and consent to participate}

The study was approved by the ethical review committee of the National Institute of Parasitic Diseases, Chinese Center for Disease Control and Prevention (No. 2014-004). Informed written consent was obtained from the subjects before collecting the stool samples and information. 


\section{Consent for publication}

Not applicable.

\section{Competing interests}

The authors declare that they have no competing interests.

\section{Author details}

'Guangzhou Institute of Pediatrics, Guangzhou Women and Children's Medical Center, Guangzhou Medical University, Guangzhou 510623, People's Republic of China. ${ }^{2}$ Department of Gastroenterology, Guangzhou Women and Children's Medical Center, Guangzhou Medical University, Guangzhou 510623, People's Republic of China. ${ }^{3}$ The Gansu Center for Disease Control and Prevention, Lanzhou 730000, People's Republic of China. ${ }^{4}$ National Institute of Parasitic Diseases, Chinese Center for Disease Control and Prevention, Shanghai 200025, People's Republic of China. ${ }^{5}$ Key Laboratory for Parasitology and Vector Biology, MOH of China, WHO Collaborating Center for Tropical Diseases, National Center for International Research on Tropical Diseases, Shanghai 20025, People's Republic of China.

Received: 2 May 2019 Accepted: 10 September 2019 Published online: 17 October 2019

\section{References}

1. Hemelaar J, Elangovan R, Yun J, Dickson-Tetteh L, Fleminger I, Kirtley S, Williams B, et al. Global and regional molecular epidemiology of HIV-1, 1990-2015: a systematic review, global survey, and trend analysis. Lancet Infect Dis. 2019;19(2):143-55.

2. Shan D, Yu MH, Yang J, Zhuang MH, Ning Z, Liu H, Liu L, et al. Correlates of HIV infection among transgender women in two Chinese cities. Infect Dis Poverty. 2018;7(1):123.

3. Ji YJ, Liang PP, Shen JY, Sun JJ, Yang JY, Chen J, Qi TK, et al. Risk factors affecting the mortality of HIV-infected patients with pulmonary tuberculosis in the CART era: a retrospective cohort study in China. Infect Dis Poverty. 2018;7(1):25.

4. Gibson RM, Nickel G, Crawford M, Kyeyune F, Venner C, Nankya I, Nabulime $E_{\text {, et }}$ al. Sensitive detection of HIV-1 resistance to zidovudine and impact on treatment outcomes in low- to middle-income countries. Infect Dis Poverty. 2017;6(1):163.

5. Tian LG, Chen JX, Wang TP, Cheng GJ, Steinmann P, Wang FF, Cai YC, et al. Co-infection of HIV and intestinal parasites in rural area of China. Parasit Vectors. 2012;5:36

6. Hosseinipour MC, Napravnik S, Joaki G, Gama S, Mbeye N, Banda B, Martinson F, et al. HIV and parasitic infection and the effect of treatment among adult outpatients in Malawi. J Infect Dis. 2007;195(9):1278-82.

7. Nsagha DS, Njunda AL, Assob NJC, Ayima CW, Tanue EA, Kibu OD, Kwenti TE. Intestinal parasitic infections in relation to CD4(+) T cell counts and diarrhea in HIV/AIDS patients with or without antiretroviral therapy in Cameroon. BMC Infect Dis. 2016;16:9.

8. Tan KS. New insights on classification, identification, and clinical relevance of Blastocystis spp. Clin Microbiol Rev. 2008;21(4):639-65.

9. Stark D, Barratt JL, van Hal S, Marriott D, Harkness J, Ellis JT. Clinical significance of enteric protozoa in the immunosuppressed human population. Clin Microbiol Rev. 2009;22(4):634-50.

10. Hunter PR, Nichols G. Epidemiology and clinical features of Cryptosporidium infection in immunocompromised patients. Clin Microbiol Rev. 2002;15(1):145-54.

11. Wang J, Gong B, Liu X, Zhao W, Bu T, Zhang W, Liu A, Yang F. Distribution and genetic diversity of Blastocystis subtypes in various mammal and bird species in northeastern China. Parasit Vectors. 2018;11(1):522.

12. Udonsom R, Prasertbun R, Mahittikorn A, Mori H, Changbunjong T, Komalamisra C, Pintong AR, et al. Blastocystis infection and subtype distribution in humans, cattle, goats, and pigs in central and western Thailand. Infect Genet Evol. 2018;65:107-11.

13. Ramírez JD, Sánchez A, Hernández C, Flórez C, Bernal MC, Giraldo JC, Reyes $P$, et al. Geographic distribution of human Blastocystis subtypes in South America. Infect Genet Evol. 2016:41:32-5.

14. Dogan N, Aydin M, Tuzemen NU, Dinleyici EC, Oguz I, Dogruman-Al F. Subtype distribution of Blastocystis spp. isolated from children in Eskisehir, Turkey. Parasitol Int. 2017;66(1):948-51.
15. Fletcher S, Caprarelli G, Merif J, Andresen D, Hal SV, Stark D, Ellis J Epidemiology and geographical distribution of enteric protozoan infections in Sydney, Australia. J Public Health Res. 2014;3(2):298.

16. Tian LG, Wang TP, Lv S, Wang FF, Guo J, Yin XM, Cai YC, et al. HIV and intestinal parasite co-infections among a Chinese population: an immunological profile. Infect Dis Poverty. 2013;2(1):18.

17. Ghimire A, Bhandari S, Tandukar S, Amatya J, Bhandari D, Sherchand JB. Enteric parasitic infection among HIV-infected patients visiting Tribhuvan University teaching hospital, Nepal. BMC Res Notes. 2016;9:204.

18. Wong KH, Ng GC, Lin RT, Yoshikawa H, Taylor MB, Tan KS. Predominance of subtype 3 among Blastocystis isolates from a major hospital in Singapore. Parasitol Res. 2008;102(4):663-70.

19. Adarvishi S, Asadi M, Cheshmeh MGD, Tavalla M, Hardani F. Prevalence of intestinal parasites in HIV-positive patients attending Ahvaz health centers in 2012: a cross-sectional study in south of Iran. Jundishapur J Chronic Dis Care. 2016;5(1):e24895.

20. Alemu A, Shiferaw Y, Getnet G, Yalew A, Addis Z. Opportunistic and other intestinal parasites among HIV/AIDS patients attending Gambi higher clinic in Bahir Dar city, north West Ethiopia. Asian Pac J Trop Med. 2011:4(8):661-5.

21. Piranshahi AR, Tavalla M, Khademvatan S. Genomic analysis of Blastocystis hominis isolates in patients with HIV-positive using locus SSU-rDNA. J Parasit Dis. 2018;42(1):28-33.

22. Li LH, Zhou XN, Du ZW, Wang XZ, Wang LB, Jiang JY, Yoshikawa $H$, et al. Molecular epidemiology of human Blastocystis in a village in Yunnan province. China Parasitol Int. 2007;56(4):281-6.

23. Zhang SX, Yang CL, Gu WP, Ai L, Serrano E, Yang P, Zhou X, et al. Casecontrol study of diarrheal disease etiology in individuals over 5 years in Southwest China. Gut Pathog. 2016;8:58

24. Zhang SX, Zhou YM, Xu W, Tian LG, Chen JX, Chen SH, Dang ZS, et al. Impact of co-infections with enteric pathogens on children suffering from acute diarrhea in Southwest China. Infect Dis Poverty. 2016;5(1):64.

25. Wang W, Owen H, Traub RJ, Cuttell L, Inpankaew T. Bielefeldt-Ohmann H3, Molecular epidemiology of Blastocystis in pigs and their in-contact humans in Southeast Queensland, Australia, and Cambodia. Vet Parasitol. 2014; 203(3-4):264-9.

26. Fekadu S, Taye K, Teshome W, Asnake S. Prevalence of parasitic infections in HIV-positive patients in southern Ethiopia: a cross-sectional study. J Infect Dev Ctries. 2013;7(11):868-72.

27. Cardoso LV, Galisteu KJ, Schiesari Júnior A, Chahla LA, Canille RM, Belloto MV, Franco C, et al. Enteric parasites in HIV-1/AIDS infected patients from a northwestern Sao Paulo reference unit in the highly active antiretroviral therapy era. Rev Soc Bras Med Trop. 2011;44(6):665-9.

28. Paboriboune $P$, Phoumindr N, Borel E, Sourinphoumy K, Phaxayaseng S, Luangkhot E, Sengphilom B, et al. Intestinal parasitic infections in HIVinfected patients. Lao People's Democratic Republic PLoS One. 2014;9(3): e91452.

29. Roka M, Goñi P, Rubio E, Clavel A. Intestinal parasites in HIV-seropositive patients in the continental region of Equatorial Guinea: its relation with socio-demographic, health and immune systems factors. Trans R Soc Trop Med Hyg. 2013;107(8):502-10.
Ready to submit your research? Choose BMC and benefit from:
- fast, convenient online submission
- thorough peer review by experienced researchers in your field
- rapid publication on acceptance
- support for research data, including large and complex data types
- gold Open Access which fosters wider collaboration and increased citations
- maximum visibility for your research: over $100 \mathrm{M}$ website views per year
At BMC, research is always in progress. 